\title{
The main directions of furniture design development
}

\begin{abstract}
In the article perspective directions of development of furniture design are reviewed and revealed based on analysis of current conditions and trends of its evolution, including the following basics: providing consumers with a wide choice of different furniture considering the vital needs and incomes of different groups of the population; a further research of new ergonomic solutions in furniture design; development and implementation of new environmentally friendly and durable materials in furniture, that ensure the health of a person; search for new and improving modern structures and materials, the use of universal and transforming furniture; introduction of innovative methods, including information technology and software management of furniture; a comprehensive consideration of the different aestethic tastes of consumers taking into account the different socio-cultural traditions. This structuring of the prospects of the development of furniture opens up the possibility of a comprehensive approach for the predicted directions of creating high-quality furniture in the near future, and will contribute to the most reliable sources defining the requirements and conditions of their realization in modern architectural environment.
\end{abstract}

Keywords: furniture design; development prospects; architectural environment

\section{Introduction}

Furniture as an element of design was in all times and remain nowadays involved in the processes of human life. They are an essential element of the environment, therefore, play an important role in creating the conditions for survival and comfort of human existence in the world.

Modern trends in the development of national and international systems of designing furniture, the process of their production, reveal the complexity and controversy of the modern requirements to them, that require constant attention, the theoretical understanding and practical update of professional activities and development of aesthetic perception of furniture as a phenomenon, and their production in accordance with the modern requirements. All of this requires the scientific validity of the results of the design, revealing and implementation of progressive trends of development of furniture design.

In many scientific studies the various aspects of designing modern furniture [1.5-14] are examined to a certain extent, as well as factors and conditions that determine the design of subject-spatial environment, including furniture [1-4, 6, $7,14]$. At the same time questions of the trends and directions of formation of modern furniture remain without proper coverage, analysis and scientific-methodical evaluation. This analysis will provide the opportunity to consider the prospects of the development of the design of modern furniture, deeply imagine the nature and subject-spatial filling of the housing and public environment and would be beneficial for its complex design and art engineering.

The purpose of this article is the definition and structuring of the main directions of the development of modern furniture design in the context of the formation of a harmonious architectural environment.

\section{The Main Part}

Furniture design should match the economic possibilities of the development of society, which affects the appropriateness and purpose of furniture, the technological level of the furniture industry, social status and level of income of person. Therefore, the socioeconomic factors and conditions largely determine the specifics, typology and features of a variety of furniture. If the conditions of planned economy in the formation of structure and main directions of development of industrial furniture manufacturing the main goal was to determine the needs of the population, the transition to a market economy requires redirecting based on accounting not only of the common needs but interests of specific customers due to their solvency. In the developed market economies gradual increasing of living standards of the population determines the growing needs of people in terms of housing, service sector facilities and leisure activities. Provision of social housing and cultural and welfare institutions and improvement of engineering equipment and comfort increase accordingly, which in turn leads to new requirements for the design of furniture, their quantitative and qualitative parameters. In case of deterioration of the economic situation of the population the structure of the aggregate income and its use changes also. Then the costs often exceed 
the revenues. Thus, a certain classification of dwellings by the level of comfort requires the typology of furniture corresponding to levels of incomes of the population, as social housing determines the use of low-cost furniture [1.3].

Creating the transformation ability of furniture in terms of minimizing the residential area allows you to change functional areas of housing when necessary, offsetting, in a certain way, the necessary square meters in the room. In conditions of insufficient living space for citizens with low income, it is necessary to create the maximum level of furniture transformation ability, using them with multifunctionality, that is, to implement the transformation of one function furiture into another or perform several functions in a single funiture unts. When perform seve ers have lack of fince so should anticipate the possibility of consistenly supplying the funiture unit with other functions for the free choice of the consumers, and if necessary - change the sequence of the trastor for transformation of furniture for consumers with an average income may decrease as their living area can be distributed according to functional needs. For consumers with a high level of income the smallest degree of furniture transformation is required, and therefore it is possible to use it in order to provide room originality, a certain style, decor, etc.

According to the socio-demographic structure of society we need to ensure the broad freedom of choice in purchasing furniture, adequate to levels of income and life needs of a diverse population. It is important also to provide various kinds of furniture for enterprises and institutions of public service under social conditions, demographic characteristics and socio-cultural patterns of consumption. However, when changing the socioeconomic and demographic characteristics of the development of society, as well as its cultural and spiritual needs we should include flexible response in the production of furniture [4].

So the first trend of furniture development is to provide the consumers with a wide choice of different furniture considering the vital needs and incomes of various population groups. The next trend refers to the active search for new ergonomic solutions. Consistency of human capabilities and technical products, reducing the negative influences of working conditions and enviring tions and environ the and the resto a min

Anthropometric furniture compliance is determined by properly chosen their spatial and functional-design parameters according to the anatomical features of the human body. Furniture design for children, especially preschool institutions, theaters, parks, attractions, etc, requires specific solutions. Special attention needs to be paid to the creation of adequate conditions of life for people with disabilities. The physiological relevance of furniture objects is characterized by features of vision, hearing, touch and smell. And all of the above should be considered when designing furniture. Aesthetic compliance that affects the emotional satisfaction from the perception of harmony of furniture in each case is determined by compositional means, such as color, scale, rhythm and proportions to achieve the visual and functional harmony in particular. It is known that the human eye can perceive no more than seven individual objects and color gamut can cause the opposite psychological condition and mood of the person.

Thus, anthropometric, physiological and aesthetic compliance of various functionalities and features of the human subject-spatial environment and conditions of work and rest are immediate conditions for manipulation of equipment and furniture systems that form specific functional areas and fill the architecturec environment and its individual parts. Therefor human ergon its individual parts. Therefore in functions furnit im design. At the same time invertive ific rement of medical specialists to scientific research of the furniture design becomes necessary. The main theme of scientific development should primarily be the impact of the human body positions in space on his health.
This aspect remains aside the requirements of furniture design till the present time.

So, to summarize what has been said, the second promising direction of the developmen of furniture design is a further search for new ergonomic solutions in furniture design. Another promising trend of the developmen of furniture design is their use as environmentally healthy product. In the design of furniture is important using durable and environmentally friendly materials and structures. The creation of "ecologically clean" micro-climate of residential structures and ensuring the organic inclusion of new furniture objects in an existing subject-spatial environment in many respects depends on their design. An important trend in the development of the furniturtant tren the improvenent of the furniture design is allowing you to reduce the costs of macesses, rests of materials, Wactucts. prodeftaining of products with fulluse of raw and materials, and

An important role in the development of the environmental aspect of the furniture design should also play environmentally friendly materials - both natural and articial or synthetic. As for the vegetable materials, the most suitable to the contact with the human body, the textiles as an environmentally friendly and lowcost product will have to stay in use and wood due to the long period of growth may lose its positions and become high-cost material in the production of furniture. Currently environmental characteristics of furniture materials are evolving, technical equipment is developing that becomes an integral part of the architectural environment. For example, new materi- als, such as MDF, heavy-duty glass, memory foam for Dormeo material, etc, are environmentally innovative materials created by the new technology. In addition, natural custom materials, such as Rattan or bamboo are actively used for the furniture. According to these phenomena modern design ideas and solutions require further improvement. And then you can formulate the next important perspective of the development of furniture: the development and implementation of of furniture: the dever that ensure the health of the person.

that ensure the health of the person. the vemely impor veloper velopme of urniture. Different characteristics of furniture direclly dere their basic structural elements, so that good design is going to substantally improve the function of the furniture unit, which in turn affects the increase of the level of comfort in the use of furniture. The geometric parameters, weight and dimensions of the furniture structures in relation to the human body are important, as well as different ways of their installation so the latest technologies of manufacture and assembly of furniture directly affect on their design. However, the important parameters of comfort is the new technical inventions in improving the functions of furniture, the introduction of new materials. The need to increase efficiency and reduce the cost of furniture leads to implementation of economic structures and materials and the use of new prospective furniture systems. Efficiency of furniture manufacturing depends not only on reducing the cost of furniture, but also on improvement performance of furniture for residential and public buildings. Yes, implementation of high-quality structures, components, materials, fittings for increased strength and durability in the production require significant funds, but the time operation costs of such systems is significantly lower.

The experience of domestic and foreign design and manufacthing practices indicates a constant improvement of tech II. 1. Samples of a mechanical arm-chairs: the apparent simplicity of the furniture is offset by the grace and elegance of the lines sensitively
balanced between the elements of shape, delicate harmony of colors and textures, high quality performance (Ergonomic Chairs at home-
decottubs). Source: decohubs.com

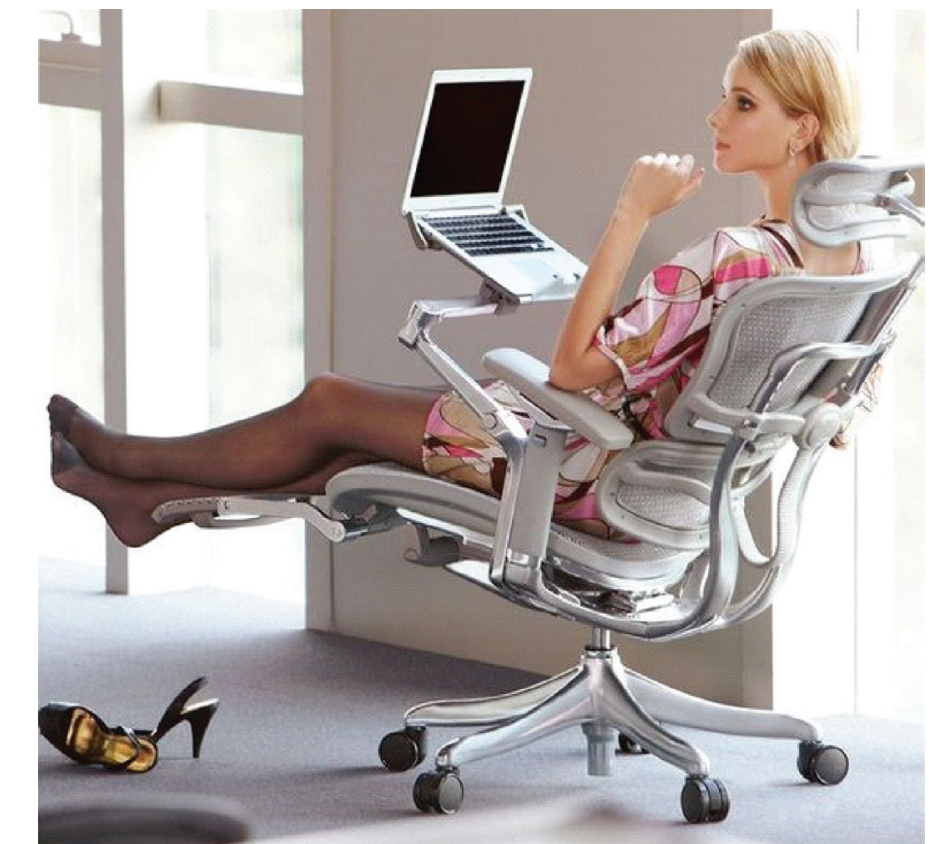

cal level of furniture design, improvement and introduction of advanced structures, technologies and products, materials, progressive equipping of furniture $[5,8,13]$. This, in turn triggers the need to further improve not only echnical, but also artistically-shaped characportant for production, which often requires innovative technical solutions for structures, innovative materials and technologies (il 1). Enhancing the equipping of objects of public use with new complex systems of transormation, vaious equipment and mechanisms mection design and technological and figurativelyspetial stuctures of furniture objects. A striking example of a quality approjh in this fietd could be an oxample of $\mathrm{Nor}$. who have dexple of Norweglan designers princip principle - leaning on the knees. This concept is combining form and structure, it is an examperspective furniture in the near future. Base Vadel of these chairs is a model of Balance Variable, created by the designer P. Opsvix. The chair has frame of molded-glued wood upholstered with leather or fabric soft seat at an angle, and two supports for the knees that are at right angles with respect to each other, which creates a natural balance, which makes all the organs of the human body function the The emergence and implementation of new materials not only diversified structurally features but determined the stylistic features

of architecture and design. Bright example of

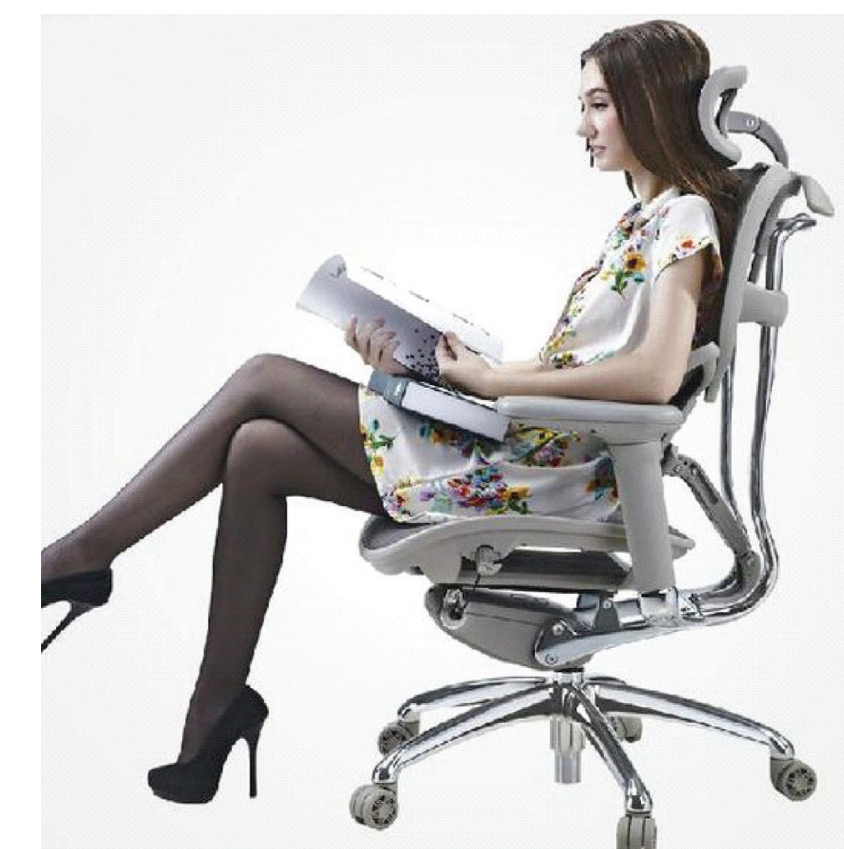
teristics of furniture, which is especially imcept fur dere most optimally, when it is in a sitting position. planning and artistically figurative furniture 
this is the widespread use of metal and polymer plastic structures. Development and introduction of new materials such as glass, plastics, polymers, MDF, PVC (Polyvinylchloride films) and many others, may subsequently affect not only the improvement of design solutions, but also to the emergence of a fundamentally new ones. Materials that furniture would be made of, in the short term should become thin-walled to reduce their weight and rational distribution of space, and the design of the furniture - mostly framed and transformthe design of the fun the - mosty framed and transforming. In aprication of pouring it significantly departed from the traditionalogy ture of ture of chairs, so new also directly afect the structure, and therefore is a promising means of influence on the evolution of furniture. High-tech production, quickly responding to requests of time, should

So, the next important perspective of the development of furniture will be: research of new and improving contemporary structures and materials, the use of universal and transforming furniture.

The intensity of the development of information technologies exceed all other industries. This development will not pass the furniture industry too. In the nearest future there may well be changes in the conditions of creative work of the designers, when author of new ideas will create projects in advanced applications, where the environment and furniture systems will not be visualized on the plane tablets, but in three dimensions.

In the near future it is worth to expect the development of such areas as increasing role of software controlled electronics in furniture, the growing role of mechanisms in the use of the furniture. Now the electronic chairs of Japanese manufacturer Raido for medical and preventive massage operations aimed at relieving fatigue and improvement of internal organs and blood circulation already operate, it is Inada D.1 Family (offers various massage techniques and applications including the vaupuncture massage of feet, thighs, arms) and

NADA W.1 Family (has infrared sensors that the chair massage with music, played by the home entertainment system (il. 2a). The electronic integration of furniture systems that will perform the command signal from a single center of the entire home or individual zones have obtained the real perspective. Perhaps, the development will take place according to the scheme of ind with their own software New techniture units ing holographic imaging functional processes that in the near future will be able to operate out in the near future wil be able to operate of the furniture, are un it may be a reproduction of fur mor example, mation ca reproduction of furntiture transfor-

An example of the growing role of robotic technical furniture systems of one- and multipurpose massage chairs is a new generation of ROBOSTIK Family and Family Sogno, produced by the Japanese company Raido, with a program to simulate maximum closenes and sense of touch of human hands for the shiatsu massage. Seats are equipped with air cells that reproduce massage all over the body, from neck to feet. Family Sogno chairs function as the unloading of the spine and rocking the seat, that tones the body and looses the spine. A person has a choice of massage action, intensity and position of rollers using a simple joystick control (fig. 2b).

Therefore, in the world practice there are ce tain trends in the furniture robotic or semi-robotic systems (fig. 3). Such furniture will have an expressive technical, electronic features an expressive technical, electronic features tions.

II. 2. Samples of electronic furniture: a) the Inada Family D.1 (medical equipment): radio.com.ua. b) Family Sogno (medical equipment): info@
radio.com
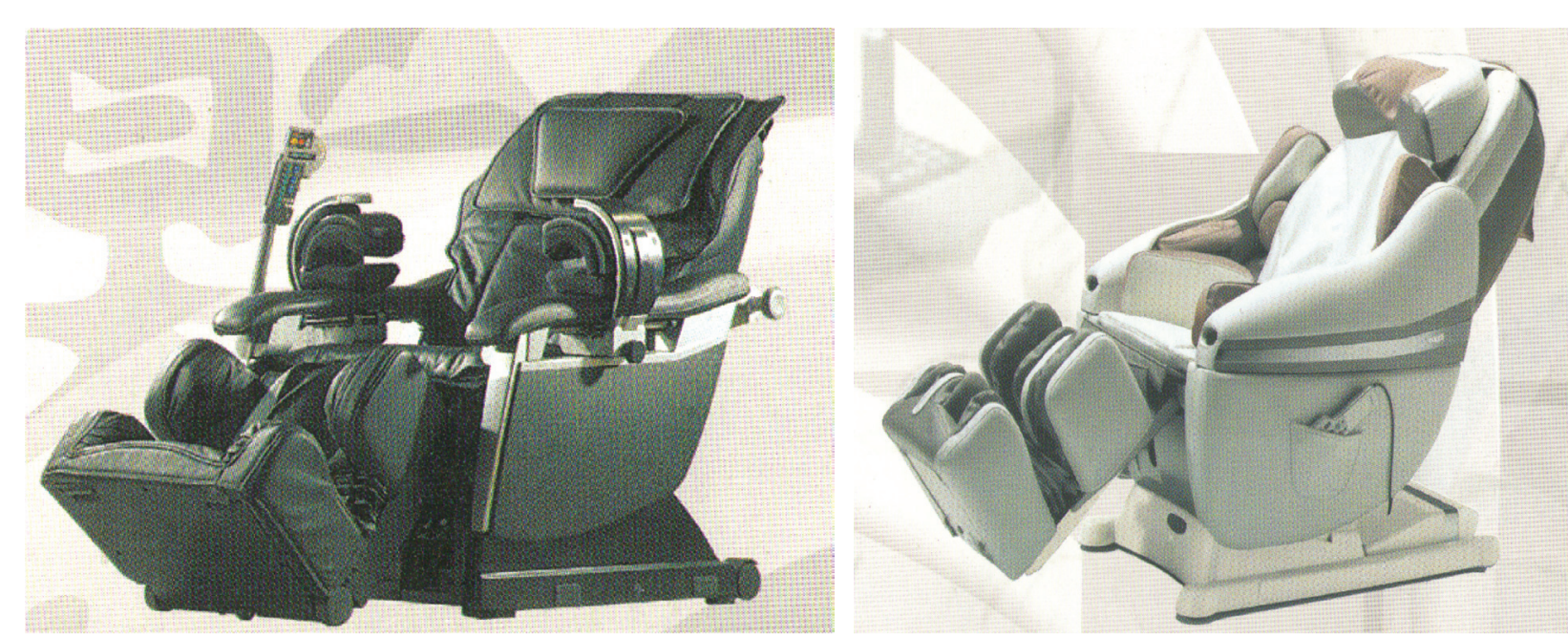

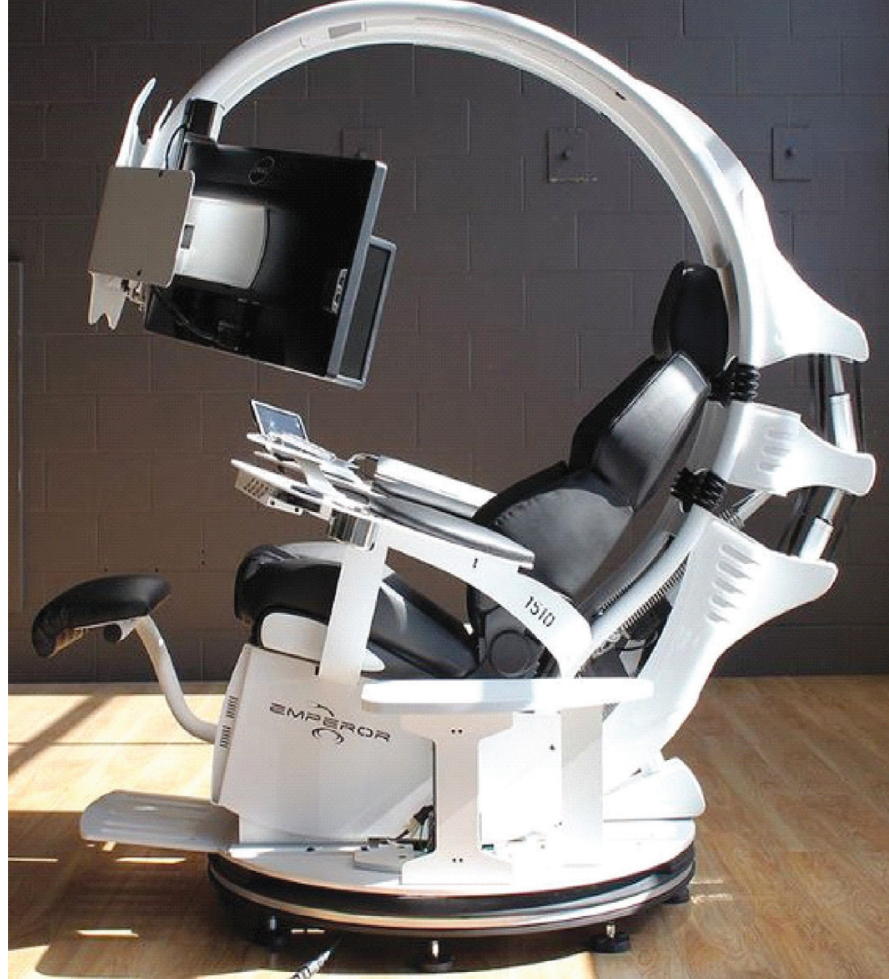

II. 3. Examples of an electronic workplaces: jojo post tech gate: man chair

of robotic signs in furniture for the disabled; such furniture directly affect the adequacy of performance of people with disabilities in various operations.

That is why the specified perspective direction of development of the furniture can be formulated as the introduction of innovative technologies, including information technology and program management.

Aesthetic factors and conditions significantly affect the formation of furniture design, which should include a broad freedom of choice as a subject-spatial forms and formation of environment of life and furniture in accordance with the

1. 4. Futuristic kitchen made of Corian - Z. Island. Author: Zaha Hadid. Ernesto-

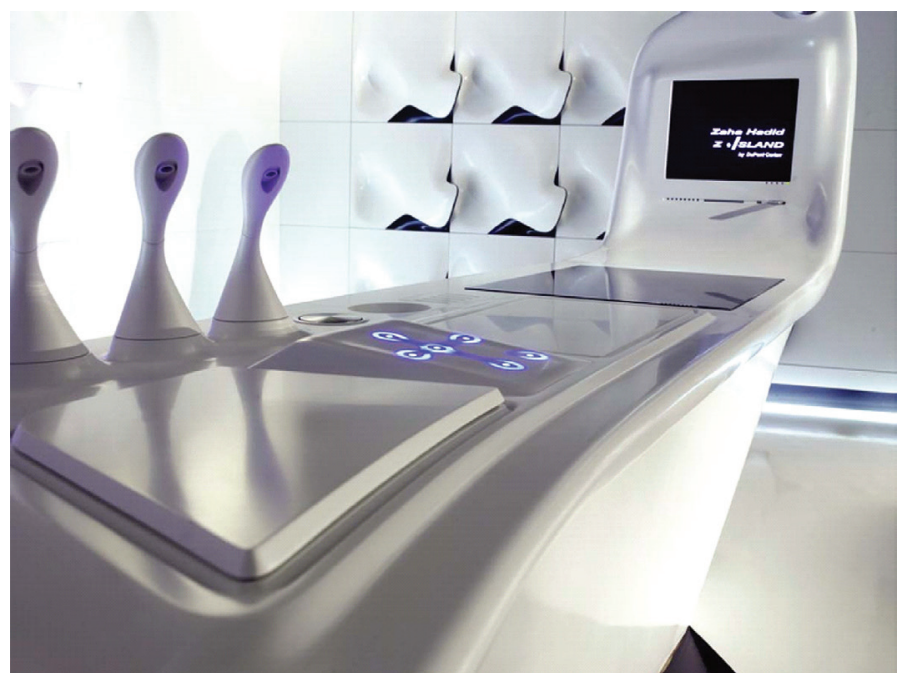

cultural and spiritual needs of a society that argely determine the creation of expressive furniture forms with a variety of art-shaped displays. This, in turn, depends on their composition-structural features. You should use the full arsenal of composition tools, such as aspect ratio, optical illusion, color, the ratio of light and shadow, emptiness and volumes of bodies, color and scale. Along with the multivariance of construction and ergonomic solutions it is important to ensure the unity of style of the whole subject-spatial environment, the integrity of the composition and visul, idenidentity as a separate unito

In addition, such aspects as creativity and vashion, individual spiritua values and the needs of the customer or the members of his family affect the overal process of combination of different aesthetic requirements. Creativity is defined by the ability to create new ideas for the formatio of the furniture, which directly affects their perception of both modern pieces. The leve of aesthetic perception for creativity is characterized by such indicators as the staging and execution of creative tasks at a high aesthetic level, color and shadow-light solution of furniture design, engineering solution of a piece of art, the originality of the design the manifestation of the creative imagination and the quest for individual style as a result of aesthetic perception of furniture designer. Fashion makes the use of composite aspects of form, color, graphics, etc. in the creation

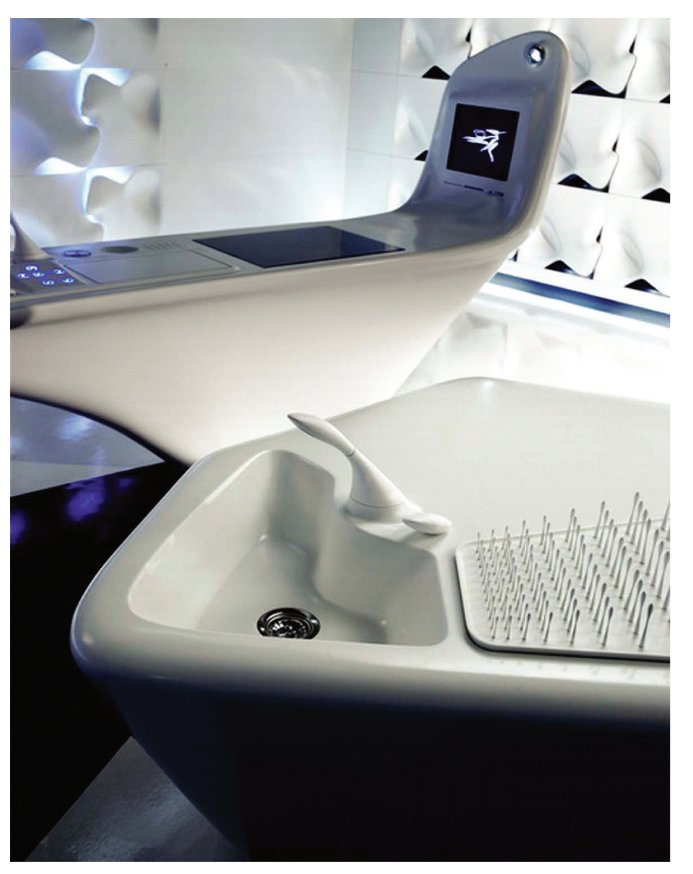


of the modern interpretation of the furniture. In a furniture design their own couturiers already appear. These are designers who can predict fashion on the furniture in the near future (fig. 4). In a democratic society the principle of respect for the individual religious values and human needs is realized. In addition, based on the principle that each person requires her environment, her own life style, which covers the style of recreation, work, etc., and the fact that everyone in his life is surrounded by things that inspire him, and are valuable concepts and characters for him, it is necessary to constantly consider in the future these important aspects when creating furniture.

There is also a very important consideration of national traditions in the design of furniture, that, on the one hand, express the spiritual-cultural mentality of the people, on the other, provide the image of furniture with unique, even exotic coloring in terms of other nations. This furniture is interesting for consumers in the international market.

This direction of furniture development can be formulated as a comprehensive consideration of the different tastes of consumers taking into account the different socio-cultural traditions.

\section{Conclusions}

Thus, on the basis of the modern conditions and trends in the evolution of the furniture main promising directions of the development of furniture design are the following:

- to provide consumers with opportunities to a wide choice of various furniture considering the vital needs and incomes of different groups of the population;

- further research of new ergonomic solutions in furniture design;

- development and implementation of new environmentally friendly and durable materials in furniture, ensuring the health of a person;

- the search for new and improving contemporary structures and materials, the use of universal and transforming;
- implementation of innovative technologies, including information technology and program management of furniture;

- comprehensive consideration of different tastes of consumers taking into account the different socio-cultural traditions.

This structuring of the prospects of the development of furniture opens up the possibility of a comprehensive approach for the predicted directions of creating high-quality furniture in the near future, and will contribute to the most reliable sources defining the requirements and conditions of their realization in modern architectural environment.

\section{BIBLIOGRAPHY:}

[1] Абизов В. А., Стрілець В. Ф. Чинники розвитку дизайну сучасних меблів в житловому та громадському середовищу, Науково-технічний збірник: проблеми розвитку міського середовища, Вип 1(17), Київ, HAУ 2017 , c. 3-14.

[2] Abyzov V., "The main factors and conditions of sustainable development", Sustainable design as a paradigm for shaping space in the 21st century, Kielce University of Technology, vol. 3, 2016, pp. 19-26.

[3] Абизов В.А., Фактори та умови, що визначають дизайн середовищних систем і об'єктів, Збірник наук. праць КНУКіМ: Мистецтвознавство, Вип. 19, Київ 2008, с. 4-17.

[4] Абизов В. А., Хартия архитектуры. Идеи нового столетия Наша епоха, 2002, с.71-73.

[5] Art Deco. Meble I sztuka uzytkowa, Warzawa: Quan um Books, 1999, 64 s.

[6] Барташевич А. А., Основы композиции и дизайна мебели, Ростовна-Дону: Феникс, 2004, 191 с.

[7] Bridge M., Encyclopedia of Deskc / Mark Bridge, London 1999.

[8] Даниленко В.Я., Дизайн: Підручник, Харків: ХДАДМ, 2003, 320 с.

[9] Грашин А. А., Краткий курс стилевой эволюции мебели : учеб. Пособие, М.: Архитектура-С, 2007, 416 c.

[10] Jates S., An Encyclopedia of Chairs / Simon Jates, London 1999.

[11] Jates S., An Encyclopedia of Tables / Simon Jates, London 1999.

[12] King C., An Encyclopedia of Sofas / Constans King, London 1999

[13] Möller R., Mobel / Renate Möller. - Munchen, Berlin : Deutscher Kunstverlag, 2005. -165

[14] Мигаль С. П., Проектування меблів: навч. посібник / С. П. Мигаль, Львів: Світ, 1999. 216 с. 